\title{
Shaking Table Sebagai Media Pembelajaran Mata Kuliah Analisis Struktur
}

\section{Dwi Shatmoko $^{1 *}$, Ganefri², Rusnardi Rahmat ${ }^{3}$}

${ }^{1}$ Program Studi Pendidikan Teknologi dan Kejuruan Program Magister, Universitas Negeri Padang, Padang, Indonesia

*e-mail: 20shatmoko.dwiko@gmail.com

\begin{abstract}
Abstrak
Masalah yang diteliti dalam penelitian ini adalah hasil belajar mahasiswa teknik sipil pada mata kuliah Analisis Struktur masih rendah. Rendahnya hasil belajar ini disebabkan oleh keterbatasan media pembelajaran yang digunakan dalam menyampaikan materi pembelajaran. Oleh karena itu, tujuan penelitian ini adalah mengembangkan media pembelajaran shaking table yang valid, praktis, dan efektif dalam meningkatkan hasil belajar. Jenis penelitian yang digunakan adalah Research and Development (R\&D) dengan prosedur pengembangan media menggunakan model 4-D. Penelitian terdiri dari empat tahap, yaitu: define, design, develop, disseminate. Data dikumpulkan menggunakan metode kuesioner dan dianalisis dengan teknik deskriptif. Hasil yang diperoleh dari penelitian pengembangan ini adalah sebuah media pembelajaran untuk mata kuliah Analisi Struktur yang valid, praktis dan efektif bagi Mahasiswa.
\end{abstract}

Kata kunci: media pembelajaran, shaking table

\begin{abstract}
Based on preliminary observation, the outcomes of civil engineering student on subject Analisis Struktur still at low level. It expected by limited media resources. Therefore, disigned and created a simulation media named shaking table for subject Teknik Gempa. The propose of research was to prove validity, practicalities and effectiveness of the tool in order to deserverd. This research was carried out of this research and development (R\&D). the model development by using Four-D model (4D). The procedure development Four-D (4D) that is Define, Design, Develop, and Disseminate. Type of data that is primary data where data that given by experts, teachers and students. Analysis techniques that the used data is a technique that is descriptive data analysis to test the validity, practicality and effectiveness module learning. The results of this development research as Produce a media used as learning media on subject Analisis Struktur is valid, practical and effective to be used as students.
\end{abstract}

Keywords: learning media, shaking table, validity, practicalities, effectiveness

\section{Pendahuluan}

Pembelajaran yang menyenangkan dapat tercipta dari sebuah media yang digunakan. Media berfungsi untuk menjelaskan atau memvisualiasasikan suatu materi yang sulit dipahami jika hanya menggunakan bahasa verbal (Sadiman, Arief., 2006). Media pembelajaran mampu memaparkan konsep rumit selain itu media juga mampu mempengaruhi sikap peserta didik (Alamsyah et al., 2018). Keberadaan media pembelajaran sangat strategis untuk mempercepat terjadi pemahaman sekaligus meningkatkan daya ingat peserta didik.

Media pembelajaran merupakan salah satu komponen sistem pembelajaran. Pembelajaran sepatutnya diorganisasikan mulai dari perencanaan, pelaksanaan hingga evaluasi. Pembelajaran yang didesain dengan baik dan memperhatikan prinsip belajar tentu akan memberikan dampak yang positif (Suyanto, 2020). Proses pembelajaran yang dilakukan oleh tenaga pengajar harus memperhatikan karakteristik dari mata kuliah dan 
perkembangan mahasiswa sehingga dalam proses pembelajaran tercipta suasana kelas yang kondusif dan semangat mahasiswa dalam mengikuti pembelajaran. Pada lingkup pembelajaran yang abstrak diperlukan sebuah media atau alat peraga yang dapat membantu proses pembelajaran sehingga akan lebih mudah memahami konsep, prinsip, proses kerja maupun membuat materi yang abstrak menjadi lebih konkret. Alat peraga mampu membantu proses belajar peserta didik dan meningkatkan hasil belajarnya (Khotimah \& Risan, 2019; Suwardi et al., 2016)

Universitas Negeri Padang (UNP) sebagai salah satu lembaga pendidikan tinggi negeri yang berada di Kota Padang memiliki peranan penting dalam meningkatkan mutu pendidikan untuk menghasilkan lulusan yang berkualitas. Salah satu mata kuliah yang terdapat di UNP adalah mata kuliah Analisis Struktur yang merupakan mata kuliah wajib yang harus ditempuh oleh mahasiswa teknik sipil. Berdasarkan Satuan Acara Pengajar (SAP) tujuan mata kuliah ini adalah mahasiswa mampu menjelaskan proses terjadinya gempa dan pengaruhnya terhadap struktur bangunan, mampu menjelaskan teknologi rekayasa struktur gedung tahan gempa, dapat menghitung kekuatan struktur bangunan sederhana akibat gaya gempa dan mampu menjelaskan karakteristik dinamis dari struktur akibat gempa.

Selama ini proses pembelajaran mengenai gempa bumi hanya berbantuan media gambar. Media gambar belum cukup membantu mahasiswa memahami tentang bagaimana terjadinya gempa bumi. Media gambar yang digunakan belum mempresentasikan secara penuh karena tidak memungkinkan menghadirkan objek tersebut secara nyata dalam wujud tiga dimensi. Beberapa kelemahan media gambar yaitu hanya menekankan persepsi indera mata, gambar benda yang terlalu kompleks kurang efektif untuk kegiatan pembelajaran, dan ukurannya sangat terbatas untuk kelompok besar (Sadiman, Arief., 2006). Keterbatasan media gambar menimbulkan kesulitan mahasiswa dalam memahami materi yang abstrak. Kesulitan yang dialami mahasiswa telah berdampak terhadap hasil belajar mahasiswa. Hal ini ditunjukkan dengan masih banyaknya mahasiswa yang mendapatkan nilai $\mathrm{C}$ dengan persetase $77,05 \%$, nilai B $17,21 \%$, nilai A $4,10 \%$ bahkan ada yang memperoleh nilai D 1,64\%.

Penurunan hasil belajar mahasiswa juga disebabkan penyampain materi secara verbal tanpa dibantu oleh sebuah media yang tepat atau alat peraga. Pembelajaran yang didominasi melalui penyajian-penyajian materi secara verbal turut menyebabkan rendahnya hasil belajar peserta didik (Yunita \& Wijayanti, 2017). Penyajian dosen dalam penyampain materi perkuliahan yang kurang menarik juga merupakan salah satu faktor prnyebab rendahnya minat belajar mahasiswa. Dosen semestinya mempunyai banyak cara dalam menyampaikan materi untuk menimbulkan daya tarik terhadap mahasiswa sehingga tidak menimbulkan kebosanan. Hal ini berkaitan dengan hasil penelitian yang menunjukkan bahwa gaya mengajar memiliki pengaruh yang signifikan terhadap hasil belajar (Djauhari, 2016).

Untuk itu diperlukan adanya media atau alat peraga untuk memudah mahasiswa memahami konsep tersebut. Hasil observasi menunjukkan bahwa dalam proses pembelajaran materi mengenai pengenalan gempa bumi hanya diberikan dalam bentuk teori dengan media pembelajaran berupa power point yang didalamnya berisi teks dan gambar saja. Ketika pembelajaran disampaikan secara informatif maka akan terjadi kesulitan belajar pada pihak peserta didik karena tidak semua peserta didik dapat memahami informasi tersebut (Kania, 2017).

Penggunaan media yang inovatif pada perkuliahan Analisis Struktur diharapkan dapat diciptakan untuk meningkatkan hasil belajar mahasiswa. Media tersebut diharapkan dapat mensimulasikan percobaan-percobaan sederhana. Percobaan sederhana tersebut memiliki beberapa variabel pada saat terjadinya gempa bumi seperti elastisitas, gaya gesekan, kecepatan gerakan serta gaya maximum dan minimum. Dengan demikian, penelitian ini fokus pada perancangan alat yang tepat untuk perkuliahan Analisis Struktur dan dapat digunakan sebagai media pembelajaran.

Peneliti memilih menggunakan alat peraga pada mata kuliah Analisis Struktur karena memiliki kelebihan untuk mendemonstrasikan suatu fenomena yang sulit diamati, 
menjelaskan konsep yang abstrak, serta dapat melakukan percobaan sesuai dengan kurikulum 2013 yang menggunakan metode scientific. Selain itu proses perkuliahan Analisis Struktur selama ini cuma dijelaskan dosen dengan ceramah atau mahasiswa hanya disuruh membaca buku terkait, maka dari itu penggunaan alat peraga pada perkuliahan ini adalah salah satu solusi dalam melakukan pembelajaran aktif dengan metode scientific.

Alat peraga yang dianggap sesuai untuk memecahkan permasalahan di atas adalah menggunakan permodelan gempa sederhana yaitu alat shaking table. Alat ini merupakan suatu permodelan getaran gempa yang dibuat untuk memudahkan mahasiswa belajar mengenai gempa bumi serta akibat yang ditimbulkannya. Alat ini dinamakan shaking table karena meja tersebut digerakan oleh motor berupa dinamo yang terhubung oleh adaptor. Getaran dari shaking table ini terbagi menjadi dua arah yaitu vertikal dan horizontal, hal ini disesuaikan pada getaran gempa bumi, yang minitik beratkan pada gelombang vertikal dan horizontal. Shaking table merupakan salah jenis media pembelajaran 3 dimensi karena dapat diraba, disentuh, dan disimulasikan. Hasil penelitian menunjukkan bahwa media pembelajaran 3 dimensi mampu meningkatkan konstrasi, membantu proses belajar, dan meningkatkan hasil (Dini et al., 2019; Hartariani et al., 2016; Ramadhan et al., 2018).

Penggunaan shaking table sebagai media belajar, diharapkan mampu membangkitkan motivasi dan rasa ingin tahu mahasiswa mengenai pengaruh gempa bumi terhadap tanah dan bangunan yang berada diatasnya. Pengoperasian alat ini sangat mudah, dan tidak memerlukan bantuan dari operator, sehingga mahasiswa dapat juga melakukan pembelajaran secara mandiri. Berdasarkan latar belakang masalah yang telah diuraikan di atas, maka peneliti ingin meneliti tentang validitas, kepraktisan, dan keefektifan alat Shaking Table sebagai media Pembelajaran pada mata kuliah analisis struktur di Jurusan Teknik Sipil Universitas Negeri Padang.

\section{Metode}

Penelitian ini menggunakan metode penelitian dan pengembangan (Research and Development/ R\&D). Model yang digunakan dalam penelitian ini adalah model pengembangan 4-D (Define, Design, Develop dan Disseminate). Tahap Penyebaran (Dessiminate) pada penelitian ini tidak dilakukan karena mengingat keterbatasan waktu dan biaya peneliti.

Produk yang telah selesai dikembangkan diuji validitas, kepraktisan, dan efektivitasnya. Uji validitas menggunakan 3 orang pakar yang dinilai ahli dalam mereview media shaking tabel. Uji kepraktisan menggunakan 1 dosen dan beberapa mahasiswa sebaga subjek coba. Uji efektivitas menggunakan satu kelas sebagai subjek coba yang menggunakan media shaking table dalam pembelajaran.

Desain uji efektivitas menggunakan desain pra eksperimen pretest posttest control group design. Sebelum shaking table diterapkan, terlebih dahulu peserta didik diberikan pretest untuk mengukur pengetahuan awal peserta didik. Setelah pretest, peserta didik diberikan pembelajaran dengan menggunakan media shaking table selama beberapa kali pertemuan. Pada pertemuan akhir diberikan posttest untuk mengetahui dampak media shaking table.

Data tentang validitas dan kepratisan media shaking table dikumpulkan menggunakan kuesioner sedangkan data efektivitas dikumpulkan menggunakan tes. Jenis tes yang digunakan adalah tes pilihan ganda sebanyak 40 butir soal. Sebelum tes diberikan terlebih dahulu diakukan uji coba soal dan dianalisis. Setelah dilakukan analisis hasil tes uji coba didapatkan 36 butir soal yang tetap dipakai dan 4 butir soal dibuang. Skor validitas dan skor kepraktisan dianalisis secara deskriptif kuantitatif sedangkan Skor yang diperoleh melalui pemberian tes dianalisis menggunakan statsitik parametrik uji-t. 


\section{Hasil dan Pembahasan}

Hasil penelitian dijelaskan mulai dari tahap pengembangan hingga pengujian. Pada tahap Define dilakukan untuk mendapatkan gambaran kondisi di lapangan. Tahapan ini menganalisis kebutuhan (needs analysis) yang diperlukan untuk proses pembuatan alat shaking table. Pada tahap ini dilakukan langkah-langkah sebagai berikut: 1) Menganalisis Satuan Acara Pengajar Mata Kuliah Analisis Struktur Analisis dilakukan dengan menelaah silabus mata kuliah Analisis Struktur. Berdasarkan SAP tujuan dari pembelajaran ini adalah agar mahasiswa mampu menjelaskan proses terjadinya gempa dan pengaruhnya terhadap struktur bangunan. Dalam melaksanakan analisis awal, peneliti melakukan observasi dan wawancara terhadap dosen yang mengampu mata kuliah dan melihat ketersediaan media pembelajaran di universitas khususnya media yang digunakan dalam memberikan materi mengenai gempa. 2) Analisis mahasiswa dilakukan dengan mewawancarai dosen yang mengampu mata kuliah Analisis Struktur. Analisis meliputi motivasi dan aktifitas mahasiswa terhaadap materi pembelajaran mata kuliah teknik gempa. Berdasarkan wawancara dengan dosen bahwa selama ini materi yang diberikan hanya berbentuk teori tanpa adanya media yang digunakan dalam pembelajaran. Media yang digunakan oleh dosen hanya berupa papan tulis dengan metode pembelajaran yang konvensional. Hal ini menyebabkan pembelajaran menjadi tidak aktif, karena kurangnya minat mahasiswa terhadap pembelajaran mata kuliah Analisis Struktur. 3) Analisis konsep dilakukan dengan berdiskusi dengan dosen dan mereview bahan ajar ataupun buku rujukan yang digunakan dalam pembelajaran. Hasil dari analisa dijadikan rujukan dalam pembuatan alat shaking table. Dalam perancangan alat ini perlu dilihat karakteristik materi yang sesuai dengan alat yang akan dirancang, hal ini bertujuan agar alat yang dirancang dapat menjadi media pembelajaran yang menarik dan meningkatkan pemahaman mahasiswa.

Tahap Perancangan (Design). Pada tahap ini dilakukan perancangan alat yang akan digunakan sebagai media pembelajaran. Tujuan dari tahap ini adalah untuk merancang sebuah alat yang dapat digunakan sebagai media, sehingga di dapatkan gambaran dari alat yang akan dikembangkan.

Tahap Pengembangan (Development). Tahap ini bertujuan untuk menghasilkan produk yang valid, praktis dan efektif. Tahapan ini terdiri dari validitas oleh validator, uji praktikalitas menurut penilaian dosen dan mahasiswa, dan uji efektivitas. Data uji coba dan hasil uji coba alat shaking table pada mata kuliah Analisis Struktur adalah sebagai berikut: 1) Tahap validasi alat shaking table pada mata kuliah Analisis Struktur Data uji validitas diperoleh dari respon validator tentang kevalidan alat yang digunakan pada perkuliahan Analisis Struktur. Validasi terdiri dari tiga orang validator. Hasil penilaian dari masing-masig aspek indikator yang diberikan validator dapat diambil rata-rata keseluruhan validasi alat shaking table adalah 0,90 sehingga dapat disimpulkan bahwa alat yang di kembangkan termasuk pada kategori "valid. Sesuai pendapat Azwar (2014: 113) hasil dari perhitungan aiken berkisar antara 0 sampai 1 dan angka 0,9 dapat diinterpretasikan memiliki koefisien cukup tinggi Untuk melihat kesepakatan antar pakar digunakan anlisis data ICC. Dari hasil analisa yang dilakukan diperoleh rata-rata nilai reliabilitas kesepakatan antar pakar $\mathrm{rxx}_{\mathrm{x}}=0,729$ dengan kategori cukup memuaskan.

Tahap Praktikalitas. Praktikalitas alat shaking table yang digunakan sebagai media pembelajaran pada mata kuliah Analisis Struktur maka dapat diketahui bahwa rata-rata skor adalah $86 \%$ dengan kategori Sangat Praktis. Respon mahasiswa tentang praktikalitas penggunaan alat shaking table sebagai media pembelajaran maka dapat diketahui bahwa rata-rata skor adalah $87 \%$ sehingga dapat disimpulkan bahwa alat yang dikembangkan ini praktis berdasarkan respon mahasiswa.

Hasil uji efektifitas alat shaking table dilihat dari hasil pretest mahasiswa (sebelum menggunakan alat) dan postest mahasiswa (setelah menggunakan alat). Untuk melihat perbandingan hasil belajar digunakan uji-t. Dari hasil analisis yang dilakukan diketahui bahwa nilai sig (2-tailed) sebesar 0,000 $<0,05$ maka sesuai dengan pengambilan keputusan paired sample t-test, maka dapat disimpulkan Ho ditolak dan Ha diterima, yang artinya terdapat perbedaan antara hasil belajar pretest dengan posttest. 
Uji t dilakukan setelah melewati tahapan uji homogenitas dan normalitas. Dari hasil analisa diketahui bahwa nilai signifikasi variabel posttest berdasarkan variabel pretest $=0,085>0,05$, artinya data variabel posttest berdasarkan variabel pretest mempunyai varian yang sama atau homogen. Sedangkan hasil analisa untuk uji normalitas adalah diketahui bahwa nilai signifikasi variabel posttest berdasarkan variabel pretest $=0,079>0,05$, artinya data variabel posttest berdasarkan variabel pretest mempunyai varian normal. Tahap penyebarluasan atau diseminasi dilakukan oleh dosen mata kuliah Analisis Struktur, guru yang akan menyebarluaskan atau memperkenalkan alat ini dikelas dan kode seksi lain pada mata kuliah Analisis Struktur.

Penelitian ini menghasilkan sebuah alat simulasi getaran gempa yang dinamakan shaking table yang dapat digunakan sebagai media pembelajaran untuk mata kuliah Analisis Struktur. Pengembangan alat ini didasarkan pada observasi awal terhadap proses pembelajaran pada mata kuliah Analisis Struktur bertujuan untuk mengetahui masalah, hambatan, serta fenomena apa saja yang ditemui di lapangan sehubungan dengan pembelajaran. Selanjutnya penulis melakukan analisis kebutuhan (need analysis), diantaranya analisis satuan acara pengajar dan identifikasi materi yang dibutuhkan. Alat ini telah melalui tahap uji validitas, praktikalitas dan efektivitas. Pada uji coba validitas dilakukan dengan cara meminta pendapat ahli melalui lembar validasi. Aspek yang divalidasi pada alat ini berisikan syarat didaktik, syarat konstruksi dan syarat teknis. Dari uji coba yang dilakukan didapatkan hasil bahwa keseluruhan aspek tersebut adalah valid. Perolehan valid ini tidak terlepas dari pengembangan shaking table yang telah memenuhi aspek didaktik, konstruksi, dan teknis. Penerapan didaktik memberikan prinsip-prinsip penyajian bahan pembelajaran dalam bahan ajar sehingga bahan ajar mampu menuntun proses belajar peserta didik (Nurmahanani, 2017; Setyono et al., 2011). Pada aspek kepraktisan bahwa shaking table termasuk kategori sangat praktis. Ini artinya bahwa media tersebut sangat mudah digunakan oleh pendidik maupun mahasiswa. Kemudahan dalam penggunaan tentu akan memberikan dapat positif kepada pendidik dan mahasiswa.

Uji efektivitas menunjukkan bahwa shaking table dapat meningkan hasil belajar. Shaking table merupakan alat peraga atau benda yang dapat memperagakan fakta, konsep, prinsip maupun prosedur menjadi lebih nyata. Kemampuan ini dimiliki oleh shaking table sehingga materi pembelajaran menjadi semakin mudah dipahami. Alat peraga akan membantu peserta didik untuk memahami materi abstrak (Ipmawan \& Kharisma, 2020; Khotimah \& Risan, 2019). Shaking table sangat membantu mengkonkretkan materi kuliah yang abstrak karena materi yang berwujud tekstual dapat dipahami melalui wujud benda 3 dimensi. Kemudahan dalam memahami materi berdampak meningkatnya pemahaman konsep oleh mahasiswa. Hal ini didukung oleh hasil penelitian lainnya yang menemukan media atau alat peraga mampu meningkatkan pemahaman konsep (Nomleni \& Manu, 2018).

Alat peraga yang digunakan dalam pembelajaran juga menimbulkan perasaan senang. Jika rasa senang sudah muncul maka aktivitas yang mahasiswa lakukan akan lebih optimal tanpa ada beban. Temuan ini didukung oleh penelitian lainnya yang juga menemukan bahwa alat peraga mampu membuat perasaan peserta didik senang dan ia melakukan aktivitas pembelajaran dengan baik (Binangun \& Hakim, 2016). Pembelajaran dengan menerapkan shaking table menunjukkan aktivitas mahasiswa lebih baik. Mahasiswa dapat berinteraksi dengan media, melakukan simulasi, dan membuat simpulan dari simulasi yang dilakukan. Temuan ini didukung oleh hasil penelitian lainnya yang menunjukkan bahwa media pembelajaran 3 dimensi mampu meningkatkan aktivitas peserta didik (Hastuti, 2007; Krisnawati \& Supriyono, 2013; Sari et al., 2019). Mahasiswa lebih tertarik mengikuti pembelajaran jika dibandingkan tanpa media atau alat peraga. Kehadiran shaking table mampu menarik perhatian mahasiswa dan terlibat dalam pemanfaatan shaking table. Hal ini sejalan hasil penelitian yang menunjukkan bahwa pemanfaatan alat peraga mampu meningkatkan perhatian peserta didik terhadap pembelajaran (Rasul et al., 2011). Sikap positif mahasiswa dapat tumbuh dengan baik 
dalam pembelajaran. Sikap positif ini sangatlah penting karena akan menentukan tahaptahapan belajar mahasiswa. Media pembelajaran mampu menumbuhkan sikap positif (Karo-Karo \& Rohani, 2018; Pinahayu, 2017).

Pembelajaran yang memanfaatkan alat peraga memiliki hasil belajar yang lebih baik dibandingkan dengan pembelajaran tanpa alat peraga (Anggraeni et al., 2017; Hidayati, 2015). Penggunaan shaking table mampu menuntun proses belajar mahasiswa secara sistematis. Pembelajaran dilakukan secara bertahap sehingga mahasiswa dapat memahami setiap tahapan dengan baik. Tidak hanya paham, mahasiswa juga dapat mengingat materi pembelajaran lebih lama karena pengalaman yang mereka peroleh lebih bermakna jika dibandingkan hanya disajikan dalam bentuk ceramah saja. Temuan ini sejalan dengan penelitian lainnya yang menunjukkan bahwa penggunaan alat peraga mampu meningkatkan daya ingat pembelajar (Li et al., 2012).

\section{Simpulan}

Proses alat shaking table hingga menjadi media pembelajaran dimulai dari tahap analisis kebutuhan hingga tahap pengujian. Hasil pengujian menunjukkan bahwa media shaking table dinyatakan valid, praktis, dan efektif meningkatkan hasil belajar. Hal ini terlihat dari perbedaan rata-rata hasil belajar setelah dan sebelum penggunaan alat shaking table. Alat peraga shaking table memiliki peran yang sangat penting dalam mengatasi kesulitan mahasiswa memahami materi dalam kuliah analisis struktur. Materi yang bersifat abstrak akan menjadi lebih konkret dengan bantuan alat tersebut. Dengan demikian, setelah menggunakan alat shaking table diharapkan mahasiswa dapat lebih memahami pembelajaran sehingga mendorong potensi diri dalam meningkatkan hasil belajar.

\section{Daftar Pustaka}

Alamsyah, R., Toenlioe, A. J. E., \& Husna, A. (2018). Pengembangan Video Pembelajaran Kepenyiaran Materi Produksi Program Televisi Untuk Mahasiswa Teknologi Pendidikan Universitas Malang. Jurnal Kajian Teknologi Pendidikan, 1(3), 229-236.

Anggraeni, H., Epon, H., \& Mulyana, E. H. (2017). Pengaruh Penggunaan Alat Peraga KIT terhadap Hasil Belajar Siswa pada Materi Katrol di Kelas V. Jurnal IImiah Pendidikan Guru Sekolah Dasar, 4(1), 10-18.

Binangun, H. H., \& Hakim, A. R. (2016). Pengaruh Penggunaan Alat Peraga Jam Sudut Terhadap Hasil Belajar Matematika. JKPM, 01(02), 204-214.

Dini, E. D. N., Chamidah, A., \& Roosyanti, A. (2019). Pemanfaatan Media Tiga Dimensi Sebagai Sarana Bangun Ruang the Utilization of Three Dimensional Media As a Means To Improve the Student S' Learning Outcomes. Jurnal Pendidikan Dasar Islam, 6(2), 183-195.

Djauhari, A. (2016). Pengaruh Gaya Mengajar Guru Dan Kebiasaan Belajar Terhadap Hasil Belajar (Studi Pada Mata Pelajaran IPS Peserta Didik Di SMP Negeri Satu. Jurnal Penelitian Dan Pendidikan IPS (JPPI), 10(3), 310-321.

Hartariani, L. L., Damayanthi, L. P. E., Wirawan, I. M. A., \& Sunarya, I. M. G. (2016). Pengembangan Media Pembelajaran 3 Dimensi Pada Mata Pelajaran Matematika Untuk Siswa Penyandang Tunagrahita (Studi Kasus: Siswa Kelas D2/Semester 2 SLB C Negeri Singaraja). Jurnal Pendidikan Teknologi Dan Kejuruan, 13(2), 137147. https://doi.org/10.23887/jptk.v13i2.8522.

Hastuti, E. (2007). Penggunaan Media Tiga Dimensi dapat Meningkatkan Hasil Belajar IPA pada Siswa Kelas IVB. Pendidikan Jurnal Sekolah Guru, 12(1), 55-62.

Hidayati, F. (2015). Pengaruh Penggunaan Alat Peraga Terhadap Prestasi Belajar Fisika Pokok Bahasan Fluida Dinamis. Jurnal Ilmiah Pendidikan Fisika, 2(2). http://jurnal.ustjogja.ac.id/index.php/COMPTON/article/view/656. 
Ipmawan, A., \& Kharisma. (2020). Pengaruh penggunaan alat peraga gatotkaca terbang terhadap hasil belajar matematika pada siswa kelas iii sekolah dasar. Jurnal ReviewPendidikan Dan Pengajaran, 3(1), 16-23.

Kania, N. (2017). Efektivitas Alat Peraga Konkret Terhadap Peningkatan Visual Thinking Siswa. THEOREMS (The Original Research of Mathematics), 1(2), 64-71.

Karo-Karo, I. R., \& Rohani. (2018). Manfaat Media dalam Pembelajaran. Axiom, 7(1), 9196.

Khotimah, S. H., \& Risan. (2019). Pengaruh Penggunaan Alat Peraga Terhadap Hasil Belajar Matematika Pada Materi Bangun Ruang. Jurnal Penelitian Dan Pengembangan Pendidikan, 4(1), 48-55. https://doi.org/10.30998/sap.v4i2.4261.

Krisnawati, A., \& Supriyono. (2013). Penggunaan Media Tiga Dimensi untuk Meningkatkan Hasil Belajar di Sekolah Dasar. Jpgsd, 01(02), 1-7.

Li, M., Tan, C. H., Teo, H. H., \& Wei, K. K. (2012). Effects of product learning aids on the breadth and depth of recall. Decision Support Systems, 53(4), 793-801. https://doi.org/10.1016/j.dss.2012.05.016.

Nomleni, F. T., \& Manu, T. S. N. (2018). Pengembangan Media Audio Visual dan Alat Peraga dalam Meningkatkan Pemahaman Konsep dan Pemecahan Masalah. Scholaria: Jurnal Pendidikan Dan Kebudayaan, 8(3), 219-230. https://doi.org/10.24246/j.js.2018.v8.i3.p219-230.

Nurmahanani, I. (2017). Penelitian Foklor Permainan Rakyat Sunda Di Kampung Cikondang Jawa Barat Dan Internalisasi Nilai Didaktisnya di Sekolah Dasar. Jurnal Pendidikan Ke-SD-An, 12(2).

Pinahayu, E. A. R. (2017). Menumbuhkan Sikap Positif Dan Kreativitas Peserta Didik Melalui Media Pembelajaran Mahjong Trigonometri. Jurnal IImiah Pendidikan Matematika, 2(1), 20-26. https://doi.org/10.26877/jipmat.v2i1.1477.

Ramadhan, R., Maulana, A., \& Rochadi, D. (2018). Pengaruh Media Pembelajaran Visual Tiga Dimensi (Sketch Up) Terhadap Hasil Belajar Siswa Pada Materi Pelajaran Macam- Macam Pekerjaan Konstruksi Kayu. Jurnal PEndidikan Teknik Sipil, 7(1), $1-10$.

Rasul, S., Bukhsh, Q., \& Batool, S. (2011). A study to analyze the effectiveness of audio visual aids in teaching learning process at uvniversity level. Procedia - Social and Behavioral Sciences, 28, 78-81. https://doi.org/10.1016/j.sbspro.2011.11.016.

Sadiman, Arief., D. (2006). Media pendidikan. PT Rajagrafindo Persada.

Sari, E., Sumarno, S., \& Setya Putri, A. D. (2019). Pengaruh Penggunaan Media Tiga Dimensi Terhadap Kemampuan Berpikir Analsisis Siswa Pembelajaran Tematik. Jurnal IImiah Sekolah Dasar, 3(2), 150. https://doi.org/10.23887/jisd.v3i2.17761.

Suwardi, S., Firmiana, M. E., \& Rohayati, R. (2016). Pengaruh Penggunaan Alat Peraga terhadap Hasil Pembelajaran Matematika pada Anak Usia Dini. JURNAL AlAZHAR Indonesia Seri Humaniora, 2(4), 297. https://doi.org/10.36722/sh.v2i4.177.

Suyanto. (2020). Desain Pembelajaran Menggunakan Teknologi Informasi Dengan Pendekatan Konstruktivistik (Blended Learning). Geography Science Education Journal, 1(2), 59-66.

Yunita, D., \& Wijayanti, A. (2017). Pengaruh Media Video Pembelajaran Terhadap Hasil Belajar Ipa Ditinjau Dari Keaktifan Siswa. Jurnal IImiah IImu Sosial Dan Humaniora, 3(2). https://doi.org/10.30738/sosio.v3i2.1614. 